\title{
Free and Total Insulin-Like Growth Factor I (IGF-I), IGF-Binding Protein-1 (IGFBP-1), and IGFBP-3 and Their Relationships to the Presence of Diabetic Retinopathy and Glomerular Hyperfiltration in Insulin- Dependent Diabetes Mellitus*
}

\author{
J. A. M. J. L. JANSSEN, M. L. JACOBS, F. H. M. DERKX, R. F. A. WEBER,
} A. J. VAN DER LELY, AND S. W. J. LAMBERTS

Department of Internal Medicine, Erasmus University, Rotterdam, The Netherlands

\begin{abstract}
The existing literature on serum insulin-like growth factor I (IGF-I) levels in insulin-dependent diabetes mellitus (IDDM) is conflicting. Free IGF-I may have greater physiological and clinical relevance than total IGF-I. Recently, a validated method has been developed to measure free IGF-I levels in the circulation.

Serum free and total IGF-I, IGF-binding protein-1 (IGFBP-1), and IGFBP-3 levels were measured in 56 insulin-treated IDDM patients and 52 healthy sex- and age-matched controls. Diabetic retinopathy was established by direct fundoscopy. In 54 IDDM patients, the glomerular filtration rate (GFR) and effective renal plasma flow were calculated from the clearance rate of $\left[{ }^{125} \mathrm{I}\right]$ iothalamate and $\left[{ }^{131} \mathrm{I}\right]$ iodohippurate sodium.

Fasting free IGF-I, total IGF-I, and IGFBP-3 levels were significantly lower in IDDM patients than in age- and sex-matched healthy controls (free IGF-I, $P<0.005$; total IGF-I, $P<0.001$; IGFBP-3, $P=$ $0.001)$, whereas IGFBP-1 levels were higher $(P<0.001)$.

In IDDM subjects, decreases in free IGF-I, total IGF-I, and IGFBP-3 levels with age were observed (free IGF-I, $\mathrm{r}=-0.27$ and $P=0.05$; total IGF-I, $\mathrm{r}=-0.52$ and $P<0.001$; IGFBP-3, $\mathrm{r}=-0.37$ and $P=0.005)$. Free IGF-I was inversely related to fasting glucose in IDDM subjects $(\mathrm{r}=-0.35 ; P=0.01)$, whereas the relationship between total IGF-I and fasting glucose did not reach significance
\end{abstract}

$(\mathrm{r}=-0.27 ; P=0.06)$

Age-adjusted free IGF-I levels were significantly higher $(P<0.05)$ in IDDM subjects with retinopathy than in subjects without retinopathy after adjustment for age.

Total IGF-I and IGFBP-3 levels were positively related to GFR (total IGF-I, $\mathrm{r}=0.35$ and $P<0.05$; IGFBP-3, $\mathrm{r}=0.28$ and $P<0.05$ ). Both of these differences lost significance after adjustment for age.

Free IGF-I, total IGF-I, and IGFBP-3 levels were lower and IGFBP-1 levels were higher in insulin-treated IDDM subjects compared to those in age- and sex-matched controls. Free IGF-I, total IGF-I, and IGFBP-3 levels decreased significantly with age in IDDM subjects. Age-adjusted free IGF-I levels in subjects with diabetic retinopathy were higher than those in subjects without diabetic retinopathy. Total IGF-I and IGFBP-3 levels were positively related to GFR in IDDM subjects, but these relations were lost after adjustment for age. Measurement of serum free IGF-I levels in IDDM subjects did not have clear advantages compared to that of total IGF-I, IGFBP-1, and IGFBP-3 levels. Serum IGF-I and IGFBPs reflect their tissue concentrations to a various degree. Consequently, extrapolations concerning the pathogenetic role of the IGF/IGFBP system in the development of diabetic complications at the tissue level remain speculative. (J Clin Endocrinol Metab 82: 2809-2815, 1997)
$\mathrm{T}$ HE LITERATURE on insulin-like growth factor I (IGF-I) in patients with diabetes is conflicting. Flyvbjerg reported that in patients with insulin-dependent diabetes mellitus (IDDM) the serum levels of IGF-I were within the normal range for the entire population (aged 20-80 yr) compared with age- and sex-matched controls (1). Therefore, Lamberton et al. concluded that serum IGF-I, measured as total IGF-I levels, probably does not play an important role in the pathogenesis of diabetic microvascular disease (2). On the other hand, Merimee et al. reported a transient rise in total serum IGF-I levels in patients with diabetes mellitus in the early phase of neovascularization of the retina (3). These

Received January 7, 1997. Revision received April 17, 1997. Accepted May 13, 1997.

Address all correspondence and requests for reprints to: Dr. Jamjl Janssen, Department of Internal Medicine III, Room D438, University Hospital Dijkzigt, Dr. Molewaterplein 40, 3015 GD Rotterdam, The Netherlands.

* This work was supported by a grant from the Netherlands Diabetes Fund. findings could not be confirmed by Hyer et al. (4) or Wang et al. (5).

Blood-borne IGF-I may also contribute to the glomerular hyperfiltration observed in early diabetic nephropathy (6). However, circulating levels of total IGF-I do not closely correlate to renal hypertrophy, and there is a lack of correlation between kidney size and the progressive decline in the glomerular filtration rate (GFR) in diabetic patients, suggesting that factors important for growth might not necessarily be involved in renal hemodynamics $(7,8)$.

Part of the controversy concerning serum IGF-I levels in IDDM may be explained by methodological problems in the IGF-I assay. Until recently, the assay methods used to measure IGF-I in serum were not able to distinguish among unbound, free IGF-I, and IGF-I bound to binding proteins (IGFBPs) (9). IGFBP-3 appears to be the primary regulator of IGF levels in response to changes in circulating GH levels and serves as a storage pool for IGF-I (10), whereas IGFBP-1 appears to be the primary regulator of IGF-I levels in response to changes in circulating insulin levels (11). 
Determination of free IGF-I instead of total IGF-I might be a way to gain insight into the concentrations and the role of the IGF-I/IGFBP system in IDDM (7). Free IGF-I, by analogy with sex and adrenal steroids and thyroid hormones, may be the major biologically active, hormonal form of IGF-I (12).

Here we report the results of a study in which we investigated the relationships of circulating free IGF-I, total IGF-I, IGFBP-1, and IGFBP-3 levels to GH release and to the presence of diabetic retinopathy and renal hemodynamics in patients with IDDM.

\section{Subjects and Methods}

\section{Subjects}

The study group consisted of 56 consecutive patients with IDDM who visited our out-patient clinic. Inclusion criteria were IDDM, age $18 \mathrm{yr}$ or older at the time of the study, age at diagnosis below $40 \mathrm{yr}$ and insulin dependency within 6 months of diagnosis, no other medication than insulin, glycosylated hemoglobin $\left(\mathrm{HbA}_{1 \mathrm{c}}\right)$ less than $11 \%$, normal serum creatinine (50-110 $\mu \mathrm{mol} / \mathrm{L})$, and no overt nephropathy (albuminuria, $<300 \mathrm{mg} / 24 \mathrm{~h}$ in 2 of 3 measurements). About half of these patients were part of a previous study in which the dynamics of GH secretion were studied (13). All patients were on an insulin dose schedule of 2-4 times daily, using combinations of short-acting and intermediate long-acting insulin. Fifty-two age- and sex-matched controls without evidence of disease were recruited from the normal urban population and staff members of our hospital to measure free and total IGF-I levels. The study was approved by the hospital ethical review committee, and all patients and volunteers gave their informed consent.

\section{Blood sampling}

Blood was collected between $0800-0900 \mathrm{~h}$ in the morning after an overnight fast in both IDDM patients as well as the control group. The last insulin injection on the day before blood sampling was administered at $2200 \mathrm{~h}$ by IDDM subjects receiving intensive insulin therapy (four daily injections, injection of an intermediate long-acting insulin at $2200 \mathrm{~h}$ ) and at $1800 \mathrm{~h}$ by IDDM subjects receiving conventional therapy (two daily injections of a mixture of short- and medium-acting insulins).

\section{Hemodynamic and renal function tests}

In 54 of 56 subjects with IDDM, renal and hemodynamic function tests were performed. The GFR and effective renal plasma flow (ERPF) were calculated from the clearance of $\left[{ }^{125} \mathrm{I}\right]$ iothalamate and $\left[{ }^{131} \mathrm{I}\right]$ iodohippurate sodium, respectively, as described in detail previously (14). Blood glucose measurements were performed every $30 \mathrm{~min}$. Glucose $(50 \mathrm{mg} /$ $\mathrm{kg} \cdot \mathrm{h}$ ) and insulin (daily dose in units divided by $100 / \mathrm{h}$ ) was given iv. To maintain the blood glucose concentration between $6.0-10 \mathrm{mmol} / \mathrm{L}$, the rate of glucose infusion was adjusted according to the blood glucose levels. The mean GFR in a group of normal subjects $(n=18,10$ men and 8 women; mean age, 39 yr; range, 25-61 yr) was 107 (range, 88-130) $\mathrm{mL} / \mathrm{min} \cdot 1.73 \mathrm{~m}^{2}$. A GFR greater than $130 \mathrm{~mL} / \mathrm{min} \cdot 1.73 \mathrm{~m}^{2}$ indicated hyperfiltration.

Blood pressure was measured every 5 min during a 60 -min period in the supine position using an automatic device (Datascope, Accutor 1a, Parasmus, NJ). The mean of at least six values between 30-60 min was calculated.

\section{Analytical methods}

The free IGF-I immunoradiometric assay (Diagnostics System Laboratories, Webster, TX) used in the present study needs no sample extraction. The assay has been previously described $(15,16)$. In short, serum samples $(100 \mu \mathrm{L})$ or recombinant human IGF-I standards were added to tubes containing a dense coating of the primary high affinity IGF-I antibody and incubated at $2 \mathrm{~h}$ at room temperature. No residual IGFBP-1 or IGFBP-3 was detectable after the first wash according to the manufacturer's data (15). The tubes were washed and incubated for $2 \mathrm{~h}$ at room temperature with the secondary radiolabeled antibody, washed three times with deionized water, and counted. The lower limit of detection is $4 \mathrm{pmol} / \mathrm{L}$. The cross-reactivity with IGF-II is less than $0.01 \%$. The intra- and interassay coefficients of variation (CVs) for the free IGF-I assay are $10.3 \%$ and $10.7 \%$, respectively, at a plasma level of $0.01 \mathrm{nmol} / \mathrm{L}$ $(\mathrm{n}=8)$.

Total IGF-I was determined by a commercially available RIA (Medgenix Diagnostics, Brussels, Belgium; intra- and interassay CVs, $6.1 \%$ and $9.9 \%$ ). Immunoradiometric assays were used for the measurement of IGFBP-1 and IGFBP-3 (Diagnostics System Laboratories; intra- and interassay CVs for IGFBP-1, 5.2\% and 6.0\%; intra- and interassay CVs for IGFBP-3, $0.56 \%$ and $1.9 \%$ ). $\mathrm{HbA}_{1 \mathrm{c}}$ was measured by high performance liquid chromatography (normal range, 5.0-6.3\%; Variant HPLC-BioRad, Veenendaal, The Netherlands), and blood glucose concentrations were measured in venous whole blood by an automatic hexokinase method (Boehringer Mannheim, Mannheim, Germany). Urinary albumin was measured with a radial immunodiffusion on agarose gel that contained $0.4 \mu \mathrm{L}$ antialbumin antiserum (Dako A 001, Dakopatts, Copenhagen, Denmark) (17). The lower limit of detection was $2 \mathrm{mg} / \mathrm{L}$, and the interassay variability was $8 \%$. The means of the results of three collection periods are presented.

\section{Diabetic retinopathy}

Diabetic retinopathy (DRP) was established by direct fundoscopy, as judged by an experienced ophthalmologist, and was graded as no DRP, background DRP, or proliferative DRP (18).

\section{Statistical analysis}

Baseline clinical characteristics are presented as the mean and range. Free IGF-I, total IGF-I, IGFBP-1, IGFBP-3, and urinary albumin excretion have a $\log$ normal distribution and are, therefore, presented as the geometric mean. IDDM subjects were compared with healthy controls. For the healthy control group we did not match on an individual basis, but performed frequency matching, i.e. selecting our controls in such a way that age and sex distribution were similar in cases and controls. For diabetic subgroups, mean and $95 \%$ confidence intervals are presented. Baseline differences between variables were analyzed with one-way ANOVA. Pearson's partial correlation coefficients were calculated to analyze the associations between variables and to test significance. Free IGF-I, total IGF-I, IGFBP-1, and IGFBP-3 did not meet the criteria for normality and were logarithmically transformed before analysis. After this transformation, a normalization of the distribution was achieved. The results presented in Table 3 were adjusted for age using linear regression analysis with (total and free) IGF-I, IGFBP-1, and IGFBP-3 as dependent variables and age and retinopathy (yes/no) as independent variables. The relations between total IGF-I and IGFBP-3, respectively, and GFR were adjusted for age using linear regression analysis with total IGF-I and IGFBP-3 as dependent variables and age and GFR as independent variables. Two-sided $P<0.05$ was considered significant. All statistical analyses were performed with Stata statistical package (Computing Resource Center, Santa Monica, CA).

\section{General characteristics}

\section{Results}

The baseline clinical characteristics of 56 IDDM subjects ( 23 women and 33 men) are presented in Table 1 . In the 52 sex- and age-matched controls, the female/male ratio was $21 / 31$ and not significantly different from that in the IDDM patients. The mean age in the control group was $34.5 \mathrm{yr}$ (SD, 13.8; range, 18-64) and did not differ from that in the IDDM group. Twenty-two of the 54 IDDM patients had a GFR above $130 \mathrm{~mL} / \mathrm{min} \cdot 1.73 \mathrm{~m}^{2}$ and were classified as hyperfiltrators.

Serum free and total IGF-I levels in the IDDM patients and control subjects are shown in Fig. 1 and Table 2. Serum free and total IGF-I levels were significantly lower in the IDDM patients than in the control group. The ratio between free IGF-I and total IGF-I levels was lower, but not statistically different, between IDDM patients and healthy controls. 
Serum IGFBP-3 levels were significantly lower and IGFBP-1 significantly higher in the IDDM patients than in the control group (Fig. 1 and Table 2).

Free IGF-I serum levels were positively related to the total

TABLE 1. Clinical characteristics of patients with IDDM

\begin{tabular}{lcc}
\hline & Mean & Range \\
\hline Age $(\mathrm{yr})$ & 36.3 & $18-63$ \\
BMI $\left(\mathrm{kg} / \mathrm{m}^{2}\right)$ & 23.8 & $16.1-37.9$ \\
Duration of diabetes $(\mathrm{yr})$ & 17.6 & $3-44$ \\
Fasting glucose $(\mathrm{mmol} / \mathrm{L})$ & 10.5 & $3.2-19.6$ \\
Hemoglobin $\mathrm{A}_{1} \mathrm{c}(\%)$ & 8.7 & $5.4-10.5$ \\
Serum creatinine $(\mu \mathrm{mol} / \mathrm{L})$ & 79 & $50-119$ \\
Albuminuria $(\mathrm{mg} / 24 \mathrm{~h})$ & 12 & $2-167$ \\
Systolic blood pressure $(\mathrm{mm} \mathrm{Hg})$ & 130 & $100-197$ \\
Diastolic blood pressure $(\mathrm{mm} \mathrm{Hg})$ & 75 & $60-101$ \\
Insulin dose $(\mathrm{IU} /$ day) & 53 & $30-78$ \\
GFR $\left(\mathrm{mL} / \mathrm{min} \cdot 1.73 \mathrm{~m}^{2}\right)$ & 126 & $59-206$ \\
ERPF (mL/min·1.73 m $\left.{ }^{2}\right)$ & 554 & $298-917$ \\
Retinopathy (no. of patients) & & \\
$\quad$ None & 29 & \\
Background & 13 & \\
Proliferative & 14 & \\
\hline
\end{tabular}

Results are presented as arrythmic mean and range; albumin is expressed as geometric mean and range, BMI, Body mass index was defined as weight (kilograms) divided by the square of height (meters); GFR, glomerular filtration rate; ERPF, effective renal plasma flow.
IGF-I concentration (IDDM, $\mathrm{r}=0.52$ and $P<0.001$; control group, $\mathrm{r}=0.47$ and $P<0.001)$ and IGFBP-3 (IDDM, $\mathrm{r}=0.33$ and $P<0.05$; control group, $\mathrm{r}=0.19$ and $P=0.17$ ) and inversely related to the IGFBP-1 concentration (IDDM, $\mathrm{r}=$ -0.40 and $P<0.005$; control group, $\mathrm{r}=-0.47$ and $P<0.001$ ). The plasma concentration of total IGF-I was positively related to IGFBP-3 (IDDM, $\mathrm{r}=0.72$ and $P<0.001$; control group, $\mathrm{r}=0.47$ and $P<0.001)$ and inversely to IGFBP-1 levels (IDDM, $\mathrm{r}=-0.42$ and $P<0.005$; control group, $\mathrm{r}=-0.56$ and $P<0.001$ ).

Both free IGF-I as well as IGFBP-3 levels decreased significantly with age in diabetic patients, whereas IGFBP-1 levels did not change with age (Fig. 2, B and C). In the normal individuals such decreases in free IGF-I and IGFBP-3 with age were not statistically significant (Fig. 2, B and C), whereas total IGF-I levels were inversely related to age in both IDDM and healthy controls (Fig. 2A). Free IGF-I and IGFBP-3 levels tended to be disproportionately lower in IDDM than healthy controls with increasing age (Fig. 2, B and C).

Free IGF-I was inversely related to fasting glucose in IDDM subjects, but not to $\mathrm{HbA}_{1 \mathrm{c}}$ (Fig. 3). The relation between total IGF-I and fasting glucose did not reach significance $(\mathrm{r}=-0.27 ; P=0.06)$, and fasting IGFBP-1 levels were positively related to fasting glucose levels in IDDM subjects
A
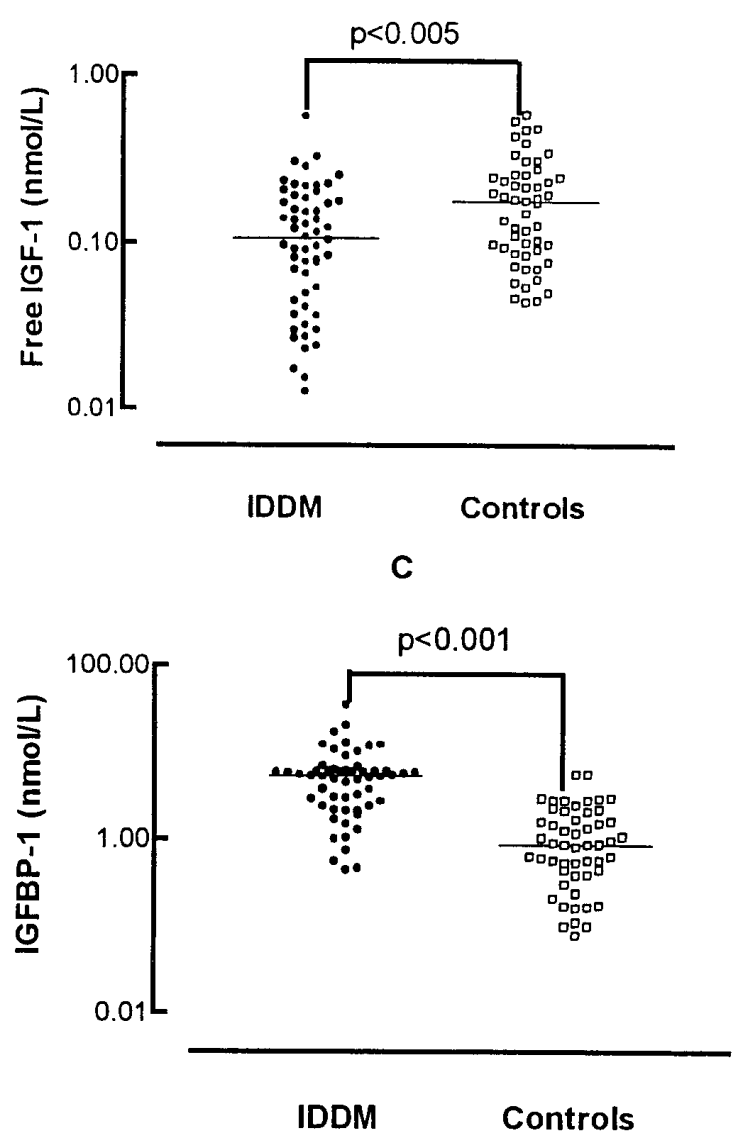

B
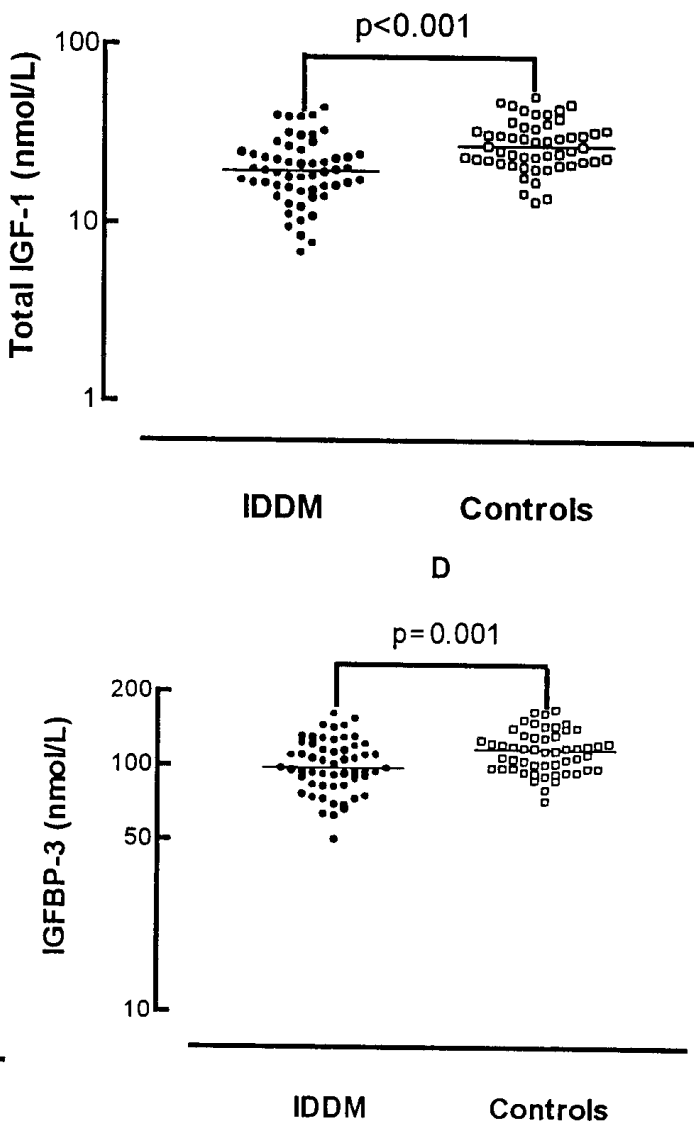

FIG. 1. Free (A) and total (B) IGF-I, IGFBP-1 (C), and IGFBP-3 (D) levels in IDDM subjects (left) and healthy controls (right). Note the logarithmic scale of the vertical axes. The bar represents the median value in each group. 
TABLE 2. Comparison of fasting total and free IGF-I, IGFBP-I, and IGFBP-3 levels between IDDM patients and (age- and sex-matched) healthy controls

\begin{tabular}{|c|c|c|c|c|c|}
\hline & \multicolumn{2}{|c|}{ IDDM } & \multicolumn{2}{|c|}{ Controls } & \multirow{2}{*}{$P$ value } \\
\hline & Mean & Range & Mean & Range & \\
\hline Free IGF-I (nmol/L) & 0.09 & $0.01-0.57$ & 0.15 & $0.04-0.58$ & $<0.005$ \\
\hline Total IGF-I (nmol/L) & 19.4 & $6.9-44.3$ & 27.6 & $13.3-51.4$ & $<0.001$ \\
\hline Free IGF-I over total IGF-I ratio $\times 100 \%$ & 0.59 & $0.11-1.99$ & 0.67 & $0.13-2.37$ & NS \\
\hline IGFBP-1 (nmol/L) & 4.1 & $0.4-35.3$ & 0.78 & $0.08-5.46$ & $<0.001$ \\
\hline IGFBP-3 (nmol/L) & 99.0 & $50.2-163.3$ & 114.6 & $79.6-170.7$ & $=0.001$ \\
\hline
\end{tabular}

Results are expressed as the geometric mean and range. The results of the free IGF-I/total IGF-I are presented as the mean.

${ }^{a}$ By ANOVA.

A

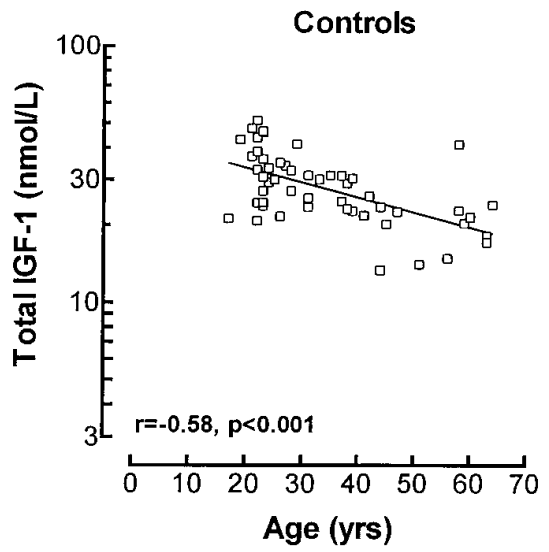

IDDM

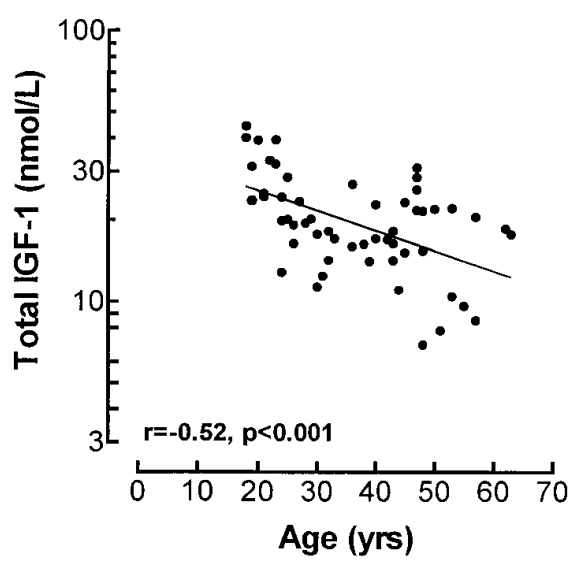

B

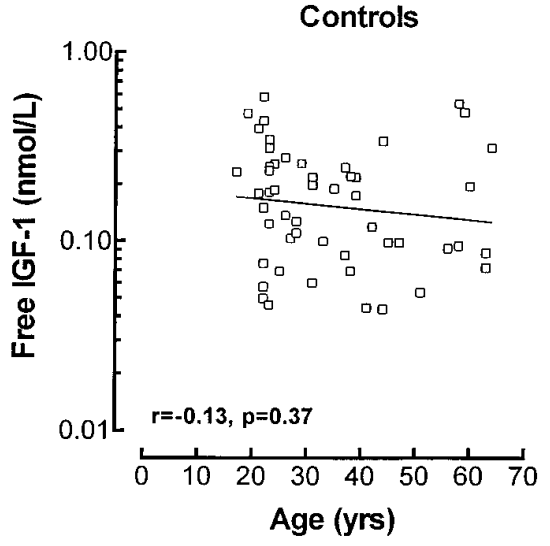

IDDM

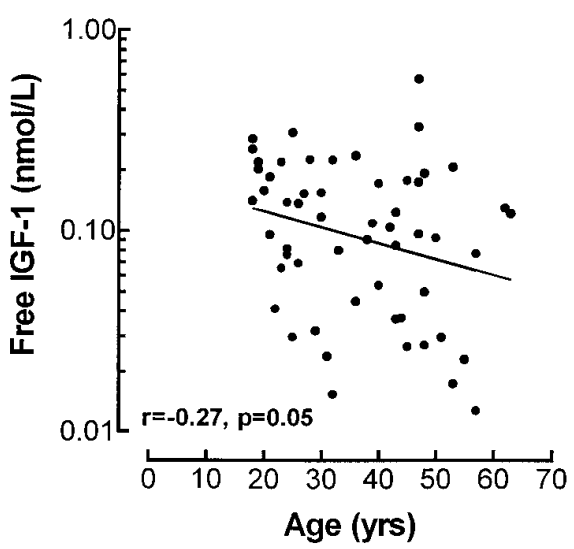

C Controls

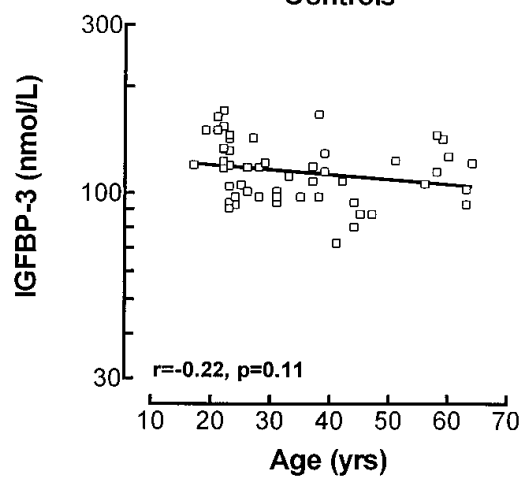

IDDM

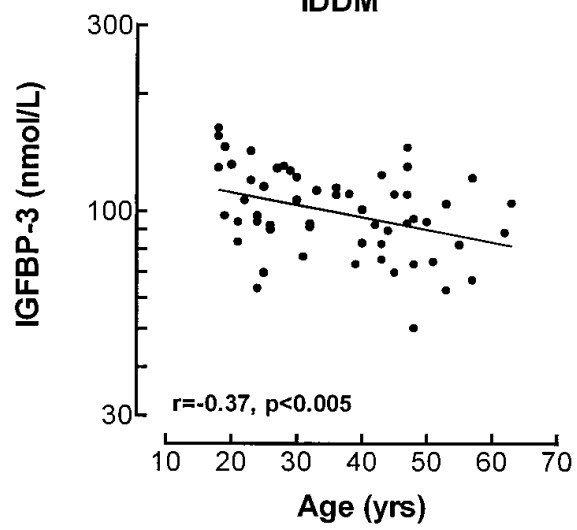

FIG. 2. Relation between age and total IGF-I levels (A), free IGF-I levels (B), and IGFBP-3 levels (C), respectively, in healthy controls (top) and IDDM patients (bottom) matched for age and sex. Note the logarithmic scale of the vertical axes.

(Fig. 3). Fasting glucose levels were positively related to $\mathrm{HbA}_{1 \mathrm{c}}(\mathrm{r}=0.36 ; P=0.01)$.

\section{IGF-I/IGFBP system in IDDM patients with retinopathy}

The 27 IDDM patients with retinopathy were older than the 29 patients without retinopathy, the duration of diabetes was longer, blood pressure was higher, and the GFR and ERPF were lower (Table 3). Free and total IGF-I, IGFBP-1, IGFBP-3, $\mathrm{HbA}_{1 \mathrm{c}}$ and fasting glucose levels were not different between the 2 groups. When adjusted for age, the patients with retinopathy tended to have higher free IGF-I levels $(P=$ $0.04)$.

\section{Renal hemodynamics}

Using $130 \mathrm{~mL} / \mathrm{min} \cdot 1.73 \mathrm{~m}^{2}$ as a cut-off, 22 patients had hyperfiltration, and 32 had a normal GFR (Table 4 ). The patients with hyperfiltration were younger, and blood pressure was not different in the two groups. In IDDM subjects, GFR decreased significantly with age $(\mathrm{r}=-0.53 ; P<0.001)$. Free IGF-I, IGFBP-1, and IGFBP-3 levels tended to be higher 
in the IDDM patients with hyperfiltration than in subjects with a GFR below $130 \mathrm{~mL} / \mathrm{min} \cdot 1.73 \mathrm{~m}^{2}$ (Table 4), but the differences were not significant.

Total IGF-I and IGFBP-3, but not free IGF-I, levels were
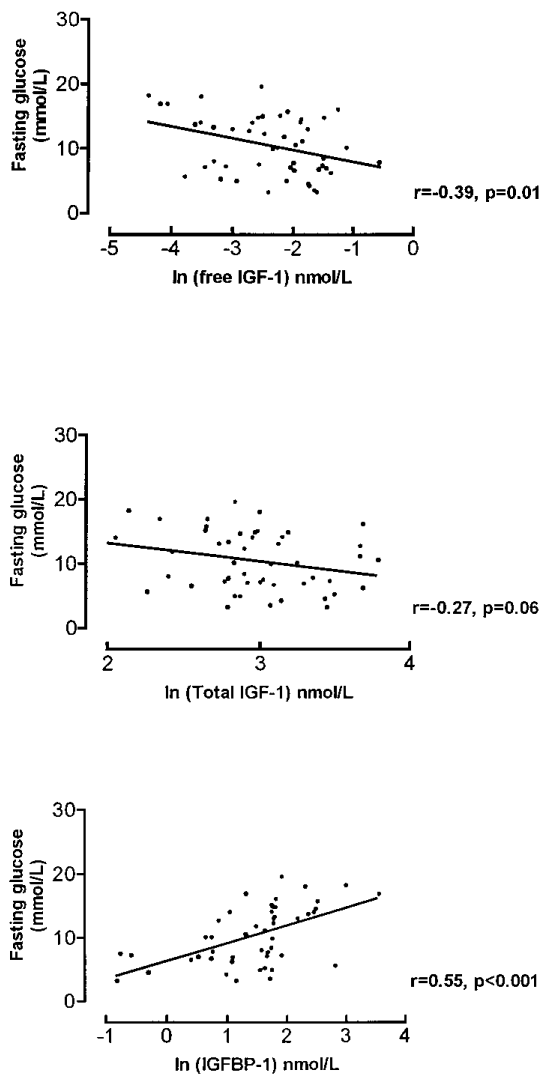

FIG. 3. Relation between fasting glucose levels and free IGF-I ( upper panel), total IGF-I (center panel), and IGFBP-1 (lower panel) levels, respectively, in IDDM subjects. Note the logarithmic scale of the horizontal axes. positively related to GFR $(\mathrm{r}=0.35$ and $P<0.05$, and $\mathrm{r}=0.28$ and $P<0.05$, respectively). The relationships between total IGF-I and IGFBP-3 levels and GFR were lost after adjustment for age.

After adjustment for fasting glucose, IGFBP-1 levels were inversely related to GFR $(\mathrm{r}=-0.30 ; P<0.05)$. Total and free IGF-I levels were not related to ERPF.

\section{Discussion}

There are many contradictory studies of IGF-I in patients with diabetes, and the methodologies used are highly variable, even between studies with similar findings. Some studies have previously found low total IGF-I and IGFBP-3 levels and high fasting IGFBP-1 levels in IDDM despite hypersecretion of GH (19-21). Our study shows that the fasting serum levels of total IGF-I (the sum of free IGF-I and IGF-I bound to an array of IGFBPs) and IGFBP-3 are lower, and IGFBP-1 levels are higher in insulin-treated IDDM patients than in an age- and sex-matched healthy control group. We also observed lower fasting free IGF-I levels in adult IDDM patients despite insulin treatment. It is likely that the free IGF-I levels measured in our study represent a combination of the true free IGF-I levels and a fraction of IGF-I that can be readily dissociated from IGFBPs under the specific assay conditions (15). Recently, free IGF-I concentrations were found to be low in untreated IDDM children using the same assay, but these concentrations tended to normalize after the start of insulin treatment (22).

We observed a significant decrease in free IGF-I and IGFBP-3 levels during aging in IDDM subjects, but not in our healthy control population. Therefore, free IGF-I and IGFBP-3 levels tended to be disproportionately lower in IDDM than in our healthy controls. A difference between IDDM subjects and healthy controls was not observed for total IGF-I levels with increasing age. In accordance with this, Graubert et al. reported that in the streptozocin-induced diabetic rat, serum free IGF-I concentrations were more depressed than

TABLE 3. Serum free IGF-I levels and other clinical characteristics of diabetic patients with and without clinically manifest diabetic retinopathy

\begin{tabular}{|c|c|c|c|c|c|}
\hline & \multicolumn{2}{|c|}{ No retinopathy $(\mathrm{n}=29)$} & \multicolumn{2}{|c|}{ Retinopathy $^{a}$} & \multirow{2}{*}{$P$ value ${ }^{b}$} \\
\hline & Mean & $95 \% \mathrm{CI}$ & Mean & $95 \% \mathrm{CI}$ & \\
\hline Free IGF-I $(\mathrm{nmol} / \mathrm{L})^{c}$ & 0.09 & $0.04-0.20$ & 0.10 & $0.04-0.23$ & NS \\
\hline Total IGF-I $(\mathrm{nmol} / \mathrm{L})^{c}$ & 21.2 & $10.0-45.1$ & 17.6 & $8.3-37.3$ & NS \\
\hline IGFBP-1 $(\mathrm{nmol} / \mathrm{L})^{c}$ & 3.98 & $2.85-5.57$ & 4.22 & $2.86-6.22$ & NS \\
\hline IGFBP-3 $(\mathrm{nmol} / \mathrm{L})^{c}$ & 104.4 & $94.8-115.1$ & 93.5 & $84.6-103.3$ & NS \\
\hline Age $(y r)$ & 29.1 & $25.3-33.0$ & 44.1 & $39.7-48.5$ & $<0.001$ \\
\hline Duration of diabetes (yr) & 12.4 & $10.4-14.5$ & 23.2 & $19.4-27.0$ & $<0.001$ \\
\hline Systolic blood pressure (mm Hg) & 125 & $120-130$ & 134 & $127-143$ & $<0.05$ \\
\hline Diastolic blood pressure ( $\mathrm{mm} \mathrm{Hg}$ ) & 73 & $69-77$ & 77 & $73-81$ & NS \\
\hline Serum creatinine $(\mu \mathrm{mol} / \mathrm{L})$ & 75 & $70-80$ & 83 & $74-91$ & NS \\
\hline $\operatorname{GFR}\left(\mathrm{mL} / \mathrm{min} \cdot 1.73 \mathrm{~m}^{2}\right)$ & 140 & $131-148$ & 111 & $102-121$ & $<0.001$ \\
\hline $\mathrm{ERPF}\left(\mathrm{mL} / \mathrm{min} \cdot 1.73 \mathrm{~m}^{2}\right)$ & 594 & $557-631$ & 514 & $473-555$ & $<0.005$ \\
\hline Albuminuria $(\mathrm{mg} / 24 \mathrm{~h})^{c}$ & 10 & 4-23 & 16 & $6-41$ & NS \\
\hline Fasting glucose (mmol/L) & 10.67 & $8.87-12.48$ & 10.27 & $8.24-12.29$ & NS \\
\hline Hemoglobin $\mathrm{A}_{1} \mathrm{c}(\%)$ & 8.77 & $8.21-9.33$ & 8.57 & $8.07-9.06$ & NS \\
\hline Insulin dose (IU/day) & 55 & $50-60$ & 52 & $46-58$ & NS \\
\hline BMI $\left(\mathrm{kg} / \mathrm{m}^{2}\right)$ & 24.0 & $21.9-26.2$ & 24.5 & $22.7-26.3$ & NS \\
\hline
\end{tabular}

For abbreviations, see Table 1 .

${ }^{a} \mathrm{n}=27 ; 13$ background and 14 proliferative.

${ }^{b}$ By ANOVA, comparing subjects with and without retinopathy; $P<0.05$ was considered statistically significant.

${ }^{c}$ Geometric mean. 
TABLE 4. Serum free IGF-I levels and other clinical characteristics of diabetic patients with glomerular hyperfiltration (GFR, $>130 \mathrm{~mL} /$ $\min \cdot 1.73 \mathrm{~m}^{2}$ ) vs. subjects without glomerular hyperfiltration (GFR, $<130 \mathrm{~mL} / \mathrm{min} \cdot 1.73 \mathrm{~m}^{2}$ )

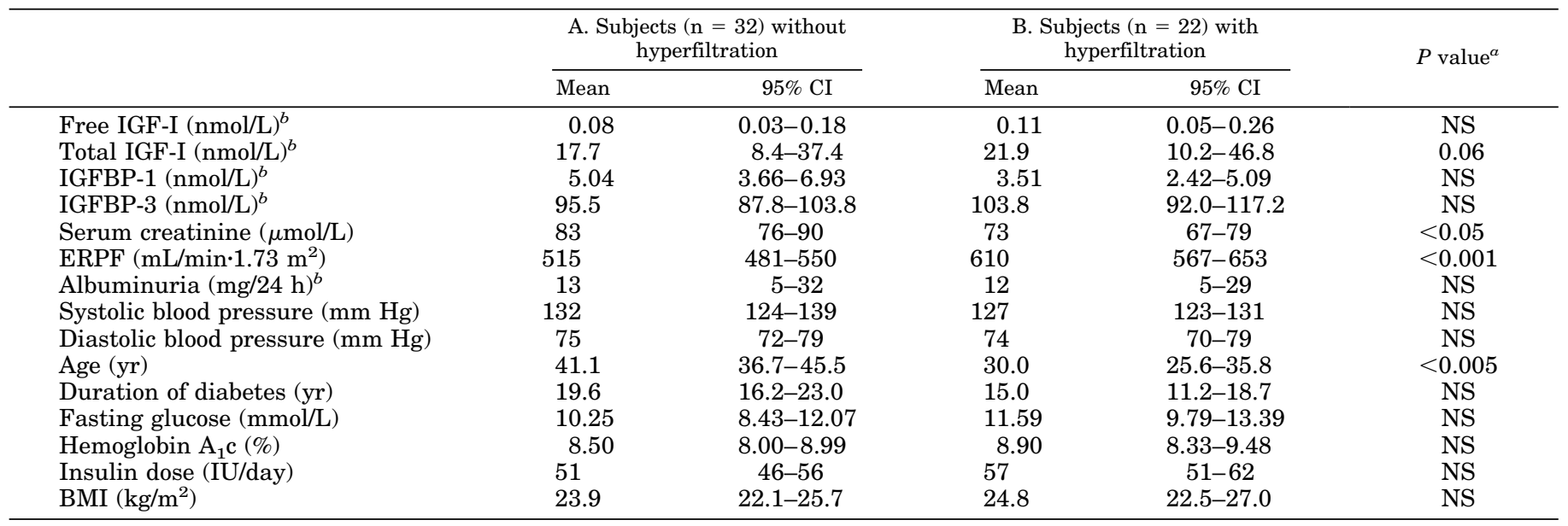

For abbreviations, see Table 1 .

${ }^{a}$ ANOVA, comparing subjects with and without hyperfiltration; $P<0.05$ was considered statistically significant.

${ }^{b}$ Geometric mean.

total IGF-I (23). Reduced free IGF-I concentrations probably account for the reduced IGF-I bioactivity in diabetic serum, as reported in earlier studies (24).

Free IGF-I levels were inversely related to fasting glucose levels in IDDM subjects, whereas fasting glucose levels were positively related to $\mathrm{HbA}_{1 \mathrm{c}}$. IGF-I exerts a tonic hypoglycemic effect in the circulation (25), and decreased IGF-I levels may induce an increase in serum glucose levels. As we observed a significant decrease in free IGF-I levels during aging in IDDM subjects, this decrease might contribute to gradually higher serum glucose levels and thereby to the development of diabetic microvascular complications (26).

IGFBP-1 levels were positively related to fasting glucose levels. A previous study in IDDM subjects also reported a positive relationship between IGFBP-1 and fasting plasma glucose levels (27). IGFBP-1 administration causes an acute rapid increase in plasma glucose levels (25), which suggests that increased IGFBP-1 levels result in decreased availability of free IGF-I levels (28). IGFBP-1 is thought to modulate the free fraction of IGF-I. The inverse relationship between free IGF-I and IGFBP-1 in our study supports the hypothesis that circulating free IGF-I levels are low(er) when IGFBP-1 levels are high (15).

Free IGF-I levels tended to be higher in IDDM patients with retinopathy after adjustment for age. However, this result needs to be interpreted with caution because retinopathy scoring was performed with direct ophthalmoscopy, a technique that may result in some misclassification of subjects and could, therefore, materially alter the results and the conclusions of our study.

An increased GFR is considered an early symptom in diabetes mellitus (29). We observed lower values for total serum IGF-I in IDDM patients than in sex- and age-matched controls, which suggests at first glance no important role for IGF-I in the pathogenesis of hyperfiltration in IDDM. Nevertheless, in our study total IGF-I levels were positively related to the GFR. The observed correlation coefficient between total IGF-I and GFR is in agreement with previous data showing that IGF-I leads to an augmentation of GFR by $10-20 \%(30,31)$. In an experimental animal model of diabetes that was characterized by increased GFR, increased binding of IGF-I to its renal IGF-I receptors was found compared to that in controls (32). Increased binding of IGF-I to the IGF-I receptor in the IDDM subjects despite low serum total IGF-I levels might also explain the observed relationship between total IGF-I and GFR in our study. However, this relationship was lost after adjustment for age, which suggests that the relationship between GFR and serum total IGF-I levels is age dependent and lost after the physiological age-dependent decrease in serum total IGF-I levels with aging.

In conclusion, free and total IGF-I and IGFBP-3 levels are lower and IGFBP-1 levels are higher in IDDM subjects than in controls. Free IGF-I and IGFBP-3 levels decrease significantly with age in IDDM subjects between 20-65 yr of age. Higher (age-adjusted) free IGF-I levels were observed in IDDM subjects with diabetic retinopathy than in subjects without retinopathy, but this difference was lost after further adjustment for glucose levels. Total IGF-I and IGFBP-3 levels were related to GFR in IDDM subjects, but this relation was lost after adjustment for age.

Measurement of serum free IGF-I levels in IDDM subjects did not provide clear advantages compared to that of total IGF-I, IGFBP-1, and IGFBP-3 levels. Serum IGF-I and IGFBPs reflect their tissue concentrations to various degrees. Consequently, extrapolations concerning the pathogenetic role of the IGF-IGFBP system in the development of diabetic complications at the tissue level remain speculative.

\section{References}

1. Flyvbjerg A, Orskov H. 1990 Growth hormone, insulin-like growth factors and diabetes. In: Alberti KGMM, Krall LP, eds. The diabetes annual. Amsterdam: Elseviers; vol 5:642-656.

2. Lamberton PR, Goodman AD, Kassoff A, et al. 1984 Von Willebrand factor (VIII R: Ag), fibronectin, and insulin-like growth factors I and II in diabetic retinopathy and nephropathy. Diabetes. 33:125-129.

3. Merimee TJ, Zapf J, Froesch ER. 1983 Insulin-like growth factors: studies in diabetes with and without retinopathy. N Engl J Med. 309:527-530.

4. Hyer SL, Sharp PS, Brooks RA, Burrin JM, Kohner EM. 1989 A two-year 
follow-up study of serum insulinlike growth factor-1 in diabetics with retinopathy. Metabolism 38:586-589.

5. Wang Q, Dills DG, Klein R, Klein BEK, Moss SE. 1995 Does insulin-like growth factor I predict incidence and progression of diabetic retinopathy? Diabetes. 44:161-164.

6. Blakesley VA, LeRoith D. 1996 The role of growth factors in the pathogenesis of diabetic vascular complications. In: LeRoith D, Taylor SI, Olefsky JM, eds. Diabetes mellitus. Philadelphia: Lippincott-Raven; 824-831.

7. Wiseman MJ, Saunders AJ, Keen H, Viberti GC. 1985 Effect of blood glucose control on increased glomerular filtration rate and kidney size in insulindependent diabetes. N Engl J Med. 155:617-621.

8. Christensen CK, Christiansen JS, Schmitz A, Christensen T, Hermansen K, Mogensen CE. 1987 Effect of continuous subcutaneous insulin infusion on kidney function and size in IDDM patients: a 2 year controlled study. J Diabetic Complications. 1:91-95.

9. NIH Conference. 1992 Insulin-like growth factors in health, and disease. Ann Intern Med. 116:854-862.

10. Jones JI, Clemmons DR. 1995 Insulin-like growth factors and their binding proteins: biological actions. Endocr Rev. 16:3-34

11. Baxter RC. 1994 Insulin-like growth factor binding proteins in the human circulation: a review. Horm Res. 42:140-144.

12. Frystyk J, Skjaerbaek C, Dinesen B, Orskov H. 1994 Free insulin-like growth factors (IGF-I and IGF-II) in human serum. FEBS Lett. 384:185-191.

13. Jacobs ML, Nathoe HMW, Blankestijn PJ, Stijnen T, Weber RFA. 1996 Growth hormone responses to growth hormone-releasing hormone and clonidine in patients with type I diabetes and normal controls: effect of age, body mass index and sex. Clin Endocrinol (Oxf). 44:547-553.

14. Zietse R, Blankestijn PJ, Pos B, et al. 1995 Optimising glomerular filtration rate and effective renal plasma flow measurements using a simple pharmacokinetic model. Clin Nephrol. 43:29-34.

15. Lee PDK, Powell D, Baker B, et al. Characterization of a direct, non-extraction immunoradiometric assay for free IGF-I. Proc of the 76th Annual Meet of The Endocrine Soc. 1994. (Abstract 939).

16. Juul A, Flyvbjerg A, Frystyk J, Muller J, Skakkebaek NE. 1996 Serum concentrations of free and total insulin-like growth factor-1, IGF binding proteins- 1 and -3 and IGFBP-3 protease activity in boys with normal or precocious puberty. Clin Endocrinol (Oxf). 44:515-523.

17. Ingild A. 1983 Single radial immunodiffusion. Scand J Immunol. 17(Suppl 10):41-56.

18. Kohner EM. The lesions and natural history of diabetic retinopathy. In: Pickup J, Williams G, eds. Textbook of diabetes. Oxford: Blackwell; 575-588.

19. Bereket A, Lang CH, Blethen SL, et al. 1995 Effect of insulin on the insulin-like growth factor system in children with new-onset insulin-dependent diabetes mellitus. J Clin Endocrinol Metab. 80:1312-1317.
20. Marshall SM, Alberti KGMM. 1993 Alterations in the growth hormone/ insulin-like growth factor 1 axis in human and experimental diabetes: differences and similarities in growth hormone and insulin-like growth factor 1 axis. In: Flyvbjerg A, Orskov H, Alberti KGMM, eds. Human and experimental diabetes. Chichester: Wiley and Sons; 23-46.

21. Brismar K, Fernqvist-Forbes E, Wahren J, Hall K. 1994 Effect of insulin on the hepatic production of insulin-like growth factor-binding protein-1 (IGFBP-1), IGFBP-3, and IGF-I in insulin-dependent diabetes. J Clin Endocrinol Metab. 79:872-878.

22. Bereket A, Lang CH, Blethen SL, Ng CL, Wilson TA. 1996 Insulin treatment normalizes reduced free insulin-like growth factor-1 concentrations in diabetic children. Clin Endocrinol (Oxf). 45:321-326.

23. Graubert MD, Goldstein S, Philips LS. 1991 Nutrition and somatomedin XXVII. Total and free IGF-I and IGF-I binding proteins in rats with streptozocin-induced diabetes. Diabetes. 40:959-965.

24. Winter RJ, Philips LS, Klein MN, Traisman HS, Green OC. 1979 Somatomedin activity and diabetic control in children with insulin-dependent diabetes. Diabetes. 28:952-954.

25. Lewitt MS, Denyer GS, Cooney GJ, Baxter RC. 1991 Insulin-like growth factor-binding protein -1 modulates blood glucose levels. Endocrinology. 129:2254-2256.

26. Reichard P, Pihl M, Rosenquist U, Sule J. 1996 Complications in IDDM are caused by elevated glucose level: The Stockholm Diabetes Intervention Study (SDIS) at 10-year follow-up. Diabetologia. 39:1483-1488.

27. Ismail IS, Miel JP, Scanlon MF, Peters JR. 1995 Effects of cholinergic modulation on serum insulin-like growth factor- 1 and its binding proteins in normal and diabetic subjects. Clin Endocrinol (Oxf). 42:147-152.

28. Cotterill AM, Daly F, Holly JMP, et al. 1995 The 'dawn phenomenon' in adolescents with insulin dependent diabetes mellitus: possible contribution of insulin-like growth factor binding protein-1. Clin Endocrinol (Oxf). 43:567-574

29. Mogensen CE, Andersen MJ.1975 Increased kidney size and glomerular filtration rate in untreated juvenile diabetes: normalization by insulin-treatment. Diabetologia. 11:221-224.

30. Guler HP, Schmid C, Zapf J, Froesch ER. 1989 Effects of recombinant insulinlike growth factor I on insulin secretion and renal function in normal human subjects. Proc Natl Acad Sci USA. 86:2868-2872.

31. Guler HP, Eckhardt KU, Zapf J, Bauer C, Froesch ER. 1989 Insulin-like growth factor I increases glomerular filtration rate and renal plasma flow in man. Acta Endocrinol (Copenh). 121:101-106.

32. Werner H, Shen-Orr Z, Stannard B, Burguera B, Roberts CT, LeRoith D. 1990 Experimental diabetes increases insulinlike growth factor I and II receptor concentration and gene expression in the kidney. Diabetes. 39:1490-1497. 